\title{
EDITORIAL
}

\section{Preface to the MME Special Focus Issue on Mine Ventilation Innovations}

\author{
Purushotham Tukkaraja ${ }^{1}$ Jürgen Brune ${ }^{2}$ \\ Published online: 21 February 2022 \\ (c) Society for Mining, Metallurgy \& Exploration Inc. 2022
}

Mine ventilation plays a critical role in the overall function of underground mines in maintaining the health and safety of miners. Ventilation systems provide fresh air to underground mine workings and dilute harmful gases, dust, and aerosols to concentrations below hazardous limits.

Mine ventilation engineering requires prudent design and maintenance of airways and ventilation controls; continuous monitoring of air quantity and quality; and control of respirable dust, diesel particulate matter (DPM), and other hazardous aerosols. Over the life of a mine, the ventilation system with fans and regulators requires continuous adjustment as miners extend drifts, open new mining panels, and seal mined-out areas.

This special focus issue highlights the following key areas of innovation in mine ventilation:

- Ventilation on demand (VOD), automation, and control technologies

- Thermal management-cooling and heating of mine air

- Changes in ventilation and cooling requirements when switching from diesel to battery-electric equipment

- Atmospheric monitoring systems (AMS); methane, gas, dust, and DPM control

- Mine ventilation planning, design, and economics
- Prevention of mine fires and explosions, including spontaneous combustion

- Main and booster fans, auxiliary ventilation, and controlled recirculation

- Research needs, mine ventilation training, and competence

Special Focus Issue Editors,

Purushotham Tukkaraja, Ph.D., QP, and Dr.-Ing. Jürgen

Brune, P.E.

Purushotham Tukkaraja, Ph.D., QP

Associate Editor, MME

Associate Professor of Mining Engineering

South Dakota Mines

PT@sdsmt.edu

Dr.-Ing. Jürgen Brune, P.E.

Professor and Associate Department Head

Mining Engineering Department

Colorado School of Mines

jbrune@mines.edu

Publisher's Note Springer Nature remains neutral with regard to jurisdictional claims in published maps and institutional affiliations.

Purushotham Tukkaraja

PT@sdsmt.edu

Jürgen Brune

jbrune@mines.edu

1 South Dakota Mines, Rapid City, SD, USA

2 Mining Engineering Department, Colorado School of Mines, Golden, CO, USA 